\title{
Conflict resolution management to support sustainable palm oil production
}

\author{
Rofikoh Rokhim ${ }^{1 *}$, Arief Wibisono Lubis ${ }^{1}$, Andrew Deni Yonathan ${ }^{1}$, and Rezza Aldan \\ Benaldi $^{1}$ \\ ${ }^{1}$ Department of Management, Faculty of Economics and Business, Universitas Indonesia, Depok, \\ 16424 , Indonesia.
}

\begin{abstract}
Palm oil is one of the major plantation commodities and contributes significantly to the GDP of Indonesia. One of the areas known for palm oil production is Jambi, where smallholder plantation dominates. The literature shows that the plantation sector is often characterized by conflicts, including small-scale farmers and big companies. Therefore, appropriate conflict management strategies should be put to mitigate these conflicts' potential adverse impacts. This paper aims to review the existing literature on conflict management strategies and examine these strategies' factors. It highlights the different conflict management styles: integrating, obliging, dominating, avoiding, and compromising. For example, the literature shows the relevance of Big Five personality, where positive relationships are documented between integrating style with conscientiousness, agreeableness, openness, and extraversion Therefore, this paper argues the importance of incorporating psychological factors in determining appropriate conflict resolution management due to this possibility of strategy implementation among actors with different psychological factors.
\end{abstract}

\section{Introduction}

Palm oil is one of Indonesia's primary plantation commodities, which has significantly become a major source of national non-oil and gas income. The demand for palm oil has been increasing. The total export value of Indonesian palm oil was USD 19 billion and contributed $17 \%$ to the agricultural sector's GDP in 2019 . While it has a significant contribution to economic growth, the palm oil sector has also been subjected to scrutiny due to its role in biodiversity loss and deforestation in several countries, including Indonesia. The issues related to sustainability surrounding the palm oil industry then emerged. The role of palm oil sector on poverty alleviation has also been investigated, where it depends on various factors, such as biophysical condition and initial socio-economic conditions [1].

In Jambi, one of Indonesia's provinces in Sumatra, palm oil is also a leading commodity in the agricultural sector's plantation sub-sector. Indonesia Palm Oil Statistics (2017) data shows how the plantation sector in Jambi, driven by the palm oil industry, has become the main driver of the regional economy by contributing $29.41 \%$ of the Gross Regional Domestic

* Corresponding author: rofikoh.rokhim@ui.ac.id 
Product (GRDP) in the province. Based on Indonesia Palm Oil Statistic data (2018), in 2017, Jambi's palm oil land area was 887,795 ha. In 2018 , the number of areas grew $16.26 \%$ to $1,032,145$ ha. Those numbers of the area contributed 7.2\% of Indonesia's total palm oil area. This growth in the number of areas is even higher than the growth of Indonesian oil palm lands nationwide, which only grew $1.98 \%$. Furthermore, based on the production level, the amount of oil palm production in Jambi in 2018 was 2,691,270 tons or $6.27 \%$ of total national production, this production level grew significantly by $45.48 \%$ from 2017 .

According to the type of ownership, Jambi's oil palm plantation area is currently dominated by smallholder plantations. Based on the Indonesia Central Statistics Agency, about 75 percent of all oil palm plantations in Jambi are categorized as smallholder oil palm plantations. Smallholder areas are part of the supply chain in oil palm agribusiness, which has recently been required to apply the sustainability aspect.

Meanwhile, given the importance of the agricultural sector, several studies have shown how this sector is prone to conflicts in developing countries, including armed conflicts [2]. Agricultural conflicts can also be found in Indonesia, where the development in the palm oil plantations has been one of the sources of conflicts. Problems related land property rights lead to conflicts between large companies and local communities. According to [3], these land property rights problems are due to insufficient consultations by the large companies with locals, community displacements, illegal operations, and lack of compensation for resettlement in the case of displacements. The statistics show that there were more than 1,700 conflicts in agriculture in between 2015-2018 [4]. Most of the conflicts are in the plantation, property, and farming sectors in the country. In 2018,83 more than $57 \%$ of the plantation sector conflict occurred in the palm oil plantation regions such as Kalimantan, Java, and Sumatera. In most of the cases, the conflicts are between households and private companies. Many conflicts which emerged in the New Order Era (1966-1998) have not been solved. Conflict would produce a high number of casualties and displacements of many people, thus creating a labor shortage in developing countries, where the agricultural sector dominates.

Some studies analyzed the effects of conflicts on the levels of agricultural outputs using farm-level at the micro-level. The findings strongly suggest that conflict could lead to negative impact in the agricultural sector in terms of labour supply, access to credit and land [5]. In addition, smallholder households exposed to conflicts had no choice other than changing land-use patterns, crop portfolios, reallocating their labor structure, and destroying or hiding their physical assets to protect their productivity [6].

There should be an appropriate conflict management design, considering the palm oil industry's susceptibility towards conflict. This study aims to discuss how conflict management strategy could alleviate conflicts between smallholders and corporations within Jambi palm oil cultivation settings. Thus, in this study, we comprehensively examine the impact of conflict resolution approaches on ongoing conflicts at several aspects in agriculture sectors. Following [7] typology, this paper argues that several aspects should be considered to design effective conflict management strategies in Indonesia's palm oil industry. Since the typology emphasizes the role of psychological factors, understanding the personalities of those in the palm oil industry, big companies, and small farmers, is essential. The usability of individual personality and situational factors to conduct long-term conflict resolution strategies [8]. The study analyzes how interpersonal conflict resolution behavior is affected by an individual's behavior and personality.

This paper is structure as follows: the following section elaborates on the method used in this study, which is primarily qualitative by reviewing the existing literature on conflict management. Afterward, we present some relevant theories related to conflict management and how they may be implemented in the context of conflicts in Indonesia's palm oil industry.

\section{Method}


This research aims to identify conflict resolution management for palm oil plantation in Jambi. It primarily uses a qualitative approach by reviewing existing literature related to conflict management. [9] posits that qualitative research is any research that produces findings not arrived at by statistical procedures or other means of quantification.

Some of the qualitative research methods are in-depth interviews, biographical methods, observations, and documents and texts' analysis [10]. In this study, we focus on reviewing and analyzing previous literature on conflict management techniques and how a model on conflict management can be implemented in the context of conflicts that often arise in the palm oil industry.

\section{Results and discussion}

\subsection{Sub conflict management process}

Several steps usually are involved in conflict management. In the first step, the party involved has to recognize the problem, and this includes sensing and formulating the problem. To recognize a problem, one needs an appropriate diagnosis. This involves identifying the conflict, its sources, and designing effective measurement and analysis of relations among them. The results of the diagnosis should indicate whether intervention is needed and interventions necessary for conflict. Then the results are discussed by conflict managers and experts in conflict research and training. Discussions concerning results should enable managers to spot conflict problems, which must be managed effectively.

Two interventions can be used in conflict if intervention is needed. The first is process, which refers to the set of activities that are performed in order to produce some desired result. The second one is structure, which means the stable arrangement of different factors of the organization, such as task and technology, so that the members can perform effective work together. A proper integration is needed in both the process and structure to achieve an organization's goals,

\subsection{Conflict management style}

Specific styles are needed to handle conflicts effectively. The appropriateness of using these styles depend on situation and several criteria related to the nature of the conflicts. As explained by [7], there are several styles in handling conflicts-integrating, obliging, dominating, avoiding, and compromising.

\subsubsection{Integrating style}

The integrating style organizes the interests of two parties. This style is useful for viably addressing complex problems within organizations. This style is acceptable when one party alone cannot find solutions to a certain problem. The style is also useful to leverage the skills, information, and other tools possessed by various parties in order to define or redefine a problem and formulate an appropriate alternative solution to it and/or when the parties' involvement is crucial to design effective solutions to the problem. This design can be achieved as long as there is enough time to troubleshoot. Integrating style is argued to be more productive than others in achieving the integration of an organization's various subsystem activities. This style is suitable for solving strategic problems. 


\subsubsection{Obliging style}

Obliging styles prefer to compromise their desires for the good of others. Obliging is characterized by uncritical thought, agreeing with the views of others. This style is ideal if the problem is only known by one party or we assume the other party is right and the problem is important to the other. The style can be used in the future to receive something from the other side. This approach is ideal for circumstances in which we consider ourselves in a vulnerable role and place importance on long-term ties.

\subsubsection{Dominating style}

Dominating style places self-interest above other people's desires by using a force inside ourselves and that nobody else has. Dominating is defined by the presence of reasons to put in contact with force experts. This style is acceptable when the issues are of high importance to the party, or the other party's wrong decisions will affect the party. This style can be used for routine problems, or when a fast decision is needed. In an organization, a superintendent might want to implement this style to deal with subordinates who are very assertive or do not possess adequate technical decision-making skills. That is also helpful when it comes to implementing unpopular initiatives.

\subsubsection{Avoiding style}

Avoiding style might not give priority to all parties' interests. Avoiding is used when individuals do not want to engage in the community and disregard conflict resolution mechanisms. Because the person is not involved in the issue, he does not want to argue that he does not want to pressure colleagues, and he hopes the situation will move through. This approach can be used when the possible negative consequences of the dispute with the other party outweigh conflict resolution benefits. That may be used to solve relatively small problems or when the organization needs stability before a complex problem can be addressed effectively.

\subsubsection{Compromising style}

The compromising style prioritizes the needs of all sides but offers only immediate dispute resolution solutions. Compromising is defined by fairness, quick-deciding short-term solutions, and maximizing profits and minimizing losses. This approach is useful when the opposing parties' interests are mutually exclusive or when both parties have equal power, and their negotiating process has reached a deadlock. It can be used when it is not possible to reach consensus, a temporary solution to a complex problem is required, or other conflict management styles have been implemented and shown to be effective in dealing with the problem. Possibly it would use this style to prevent prolonged conflict.

\subsection{Psychological factors and conflict management}

Although the criteria, as mentioned earlier, should be considered in deciding which conflict management style to implement, research has shown that the choice of strategies cannot be separated from psychological factors. There are many facets of psychological factors. One of the most commonly examined is the Big Five personality. That factors consist of openness, conscientiousness, extraversion, agreeableness, and neuroticism [11]. Openness reflects a desire for uniqueness, variety, and change. Conscientiousness reflects dependability and responsibility. Extraversion reflects cheerfulness and positive social traits. Agreeableness 
reflects cooperativeness and trust in others. Neuroticism tends to experience negative emotions, such as guilt and anxiety [11].

There is a positive relationship between integrating style with conscientiousness, agreeableness, openness, and extraversion [12]. Meanwhile, a positive relationship is documented between dominating style and extraversion. Then, negative relationships are found between this style and agreeableness and neuroticism. On the other hand, avoiding style has negative correlations with openness, conscientiousness, extraversion. It has positive associations with agreeableness and neuroticism. It should be noted that these relationships are not universal across situations, as other references found different results in terms of integrating style where it has a negative relationship with openness and a positive correlation with neuroticism [8]. In contrast, the dominating style is shown to correlate with neuroticism [12][13]. [14] conducted a metanalysis on the relationship between Big Five personality and conflict management style. The result shows that there are positive relationships between extraversion, conscientiousness, openness to experience, and agreeableness with compromising style. They also highlighted the importance of worksetting, particularly in the relationship between neuroticism and compromising style. Therefore, it indicates an understanding of psychological factors is crucial in conflict resolution management, including palm oil plantation in Jambi.

\section{Conclusion}

The palm oil sector is susceptible to conflict, and studies have shown that conflicts in the agricultural sector can severely impact the entire supply chain. That is also the case in Jambi, Indonesia, where small palm oil farmers dominate in terms of numbers. Therefore, it is crucial to identify appropriate conflict management styles. Conflict management theory points out that there are five major conflict management styles: integrating, obliging, dominating, avoiding, and compromising. The effectiveness of these styles is contextual, and there is a tendency that psychological factors play an important role in predicting which style is most likely implemented. Therefore, it is argued that considering these factors is crucial in designing conflict management strategies. Since psychological traits are multifaceted, identifying which psychological aspect matters is not a straightforward task. One framework that can be used is the Big Five personality factor. Further studies might attempt to first examine the Big Five profile of parties often involved in agricultural conflicts, to see the types of conflict management styles that might likely be implemented.

\section{Acknowledgements}

This research is funded by Program Penelitian Dasar Ungguan Perguruan Tinggi (PDUPT) Kementerian Riset dan Teknologi/Badan Riset dan Inovasi Nasional (KEMENRISTEK/BRIN)Universitas Indonesia with contract number 8/E1/KP.PTNBH/2020 and 255/PKS/R/UI/2020

\section{References}

1. T. Santika, S. Budiharta, E.A. Law, R.A. Dennis, A. Dohong, M.J. Struebig, M. Medrilzam, H. Gunawan, E. Meijaard, and K.A. Wilson, "Interannual climate variation, land type and village livelihood effects on fires in Kalimantan, Indonesia", Global Env. Cha., vol. 64, 2020.

2. A. Adelaja and J. .George, "Effects of conflict on agriculture: Evidence from the Boko Haram insurgency”, World Dev., vol. 117, pp. 184-195, 2019. 
3. N.K. Abram, E. Meijaard, K.A. Wilson, J.T. Davis, J.A. Wells, M. Ancrenaz, S. Budiharta, A. Durrant, A. Fakhruzzi, R.K. Runting, D. Gaveau, and K. Mengersen, "Oil palm-community conflict mapping in Indonesia: A case for better community liaison in planning for development initiatives“, App. Geo., vol. 78, pp. 33-44, 2017.

4. Konsorsium Pembaruan Agraria, "Catatan akhir tahun 2018: Masa depan reforma agraria melampaui tahun politik", 2018.

5. C. Blattman and E. Miguel, "Civil war", J. Econ. Lit., vol 48, no. 1, pp. 3-57, 2010

6. M. A. Arias, A. M. Ibáñez, and A. Zambrano, "Agricultural production amid conflict: Separating the effects of conflict into shocks and uncertainty", World Dev., 2018.

7. M. A. Rahim, Managing Conflict in Organizations (3rd ed.), Westport, CT: Quorum Books, 2001.

8. H. Park and D. Antonioni, "Personality, reciprocity, and strength of conflict resolution strategy", Journal of Research in Personality, 2007.

9. A. L. Strauss and J. Corbin, Basics of Qualitative Research: Grounded Theory Procedures and Techniques, 2nd edition, Thousand Oaks, CA: Sage, 1998.

10. J. Ritchie and J. Lewis, Qualitative Research Practice: A Guide for Social Science Students and Researchers, London: Sage Publications, 2003.

11. P. T. Costa and R. R. McCrae, The Five-Factor Model and the NEO Inventories. In J. N. Butcher (Ed.), Oxford library of psychology. Oxford Handbook of Personality Assessment, pp. 299-322, Oxford University Press, 2009.

12. D. Antonioni, "Relationship between the big five personality factors and conflict management style”, Int. J. Confl. Manag., vol 9, pp. 336-355, 1998.

13. M. Aliakbari and M. Amiri, "Personality, face concern, and interpersonal conflict resolution styles: A case of Iranian college students", Pers. and Individ. Differ., vol. 97, pp. 266-271, 2016.

14. H.D. Tehrani and S. Yamini, "Personality traits and conflict resolution styles: A metaanalysis", Pers. Individ. Differ., vol. 157, 2020. 